\title{
The enhancement by dietary zinc deficiency of the susceptibility of the rat duodenum to colchicine
}

\author{
By D. DINSDALE AND R. B. WILLIAMS \\ The Rowett Research Institute, Bucksburn, Aberdeen, $A B 2{ }_{9} S B$ \\ (Received 22 March 1976-Accepted 4 May 1976)

\begin{abstract}
I. The incidence of colchicine-induced lesions in the germinal epithelium of the rat duodenum was studied in young rats in an early stage of zinc deficiency and in their pair-fed controls. At both dose levels of colchicine used, a marked increase in the amount of cell damage was observed in the duodenum of $\mathrm{Zn}$-deficient rats as compared with the pair-fed, control ( $\mathrm{Zn}$-supplemented) rats.

2. No statistical interaction between $\mathrm{Zn}$ and colchicine was demonstrable, and no lesions were found in the duodenum of animals that had not been treated with colchicine.

3. The results are discussed in relation to the effects of $\mathrm{Zn}$ deficiency in animals and the possible involvement of $\mathrm{Zn}$ in the maintenance of the integrity of microtubular structures.
\end{abstract}

In earlier work (Fell, Leigh \& Williams, I973) it was reported that the cytotoxic effects of colchicine on the rat pancreas were exacerbated under conditions of dietary zinc deficiency. In other tissues then examined (oesophagus, skin and liver) the effects of this drug appeared to be limited to metaphase arrest of dividing cells. That a tissuespecific response occurred is not surprising in view of the fact that in dietary $\mathrm{Zn}$ deficiency the loss of $\mathrm{Zn}$ from different organs or tissues varies considerably (Prasad, Oberleas, Wolf \& Horwitz, 1967; Reinhold, Kfoury \& Thomas, 1967; Williams \& Mills, 1970) and that the accumulation of colchicine also varies widely between different tissues (Back, Walaszek \& Uyeki, I95I). The inference to be drawn from these earlier findings, i.e. that $\mathrm{Zn}$ may be able to exert some protective effect against colchicine toxicity, appeared to be related to the findings of Fujii (1954, 1955) that an important aspect of $\mathrm{Zn}$ metabolism is the association of this metal with the mitotic spindle and hence microtubules of the cell. Positive identification of $\mathrm{Zn}$ in the mitotic apparatus has been made (Morisawa \& Mohri, 1972).

The cytotoxic effects of colchicine may be related to its ability to bind to the protein dimer subunit of the microtubular protein, tubulin (Weisenberg, Borisy \& Taylor, I968), and thus induce the disaggregation of the microtubular arrays of the cell (Taylor, 1965). The results of studies in vitro of Nickolson \& Veldstra (1972) indicated that, of a number of heavy metals tested, $\mathrm{Zn}$ alone was able to inhibit the binding of colchicine to tubulin dimers and, at the same time, preserve the morphology of intact neurotubules.

In view of these findings it seemed desirable to determine whether, in the rat, dietary $\mathrm{Zn}$ status could be further related to the severity of the effects of colchicine toxicity. The choice of the duodenum as the tissue to be studied was influenced by the high mitotic rate of this tissue, the swift decrease in the activity of $\mathrm{Zn}$-associated enzymes in the gut of $\mathrm{Zn}$-depleted animals (Mills, Quarterman, Williams, Dalgarno \& Panic, 
r967; Williams, 1972) and the known accumulation of colchicine in the duodenum (Back et al. 1951).

\section{EXPERIMENTAL}

\section{Animals and diets}

Male weanling Hooded Lister rats of the Rowett Institute strain were housed individually in glass and Perspex cages and were given ad lib. an egg-albumen based diet containing $40 \mathrm{mg} \mathrm{Zn} / \mathrm{kg}$ as previously described (Williams \& Mills, 1970). When they had reached a weight of approximately $80 \mathrm{~g}$, the rats were paired according to weight and one of each pair allocated at random to the $\mathrm{Zn}$-deficient group and offered a similar diet with no $\mathrm{Zn}$ supplement $(\mathrm{Zn}$ content $<1 \mathrm{mg} / \mathrm{kg}$ ). The other rat was pair-fed the $\mathrm{Zn}$-supplemented diet. Growth of the low-Zn rats ceased on the $5^{\text {th }}$ day and thereafter their food intake became erratic. From the $\mathrm{I} 2$ th day after offering the low-Zn diet all animals were given a constant amount of food $(6.5 \mathrm{~g} / \mathrm{d})$ for a further $4 \mathrm{~d}$, which all could ingest, to obviate any effects of differing food intake on intestinal mitotic rhythms (Alov, 1963).

\section{Treatments}

Expt I. Six pairs of animals, as described previously, were used. At the end of the $4 \mathrm{~d}$ constant food intake period, all the rats were injected, subcutaneously, with colchicine (BDH Ltd, Poole, Dorset), two pairs at each of the dose rates of $0.2,1 \cdot 0$ or $2.0 \mathrm{mg} / \mathrm{kg}$ live weight. They were killed by a blow to the head $6 \mathrm{~h}$ later.

Expt 2. Nine pairs of animals were used. Preliminary studies of tissue from Expt I indicated that particular attention should be paid to the effects of the two higher dose rates of colchicine. In this experiment three $\mathrm{Zn}$-deficient animals and their controls were injected with colchicine at a level of $\mathrm{I} .0 \mathrm{mg} / \mathrm{kg}$ live weight, and three further animals on each diet received doses at $2.0 \mathrm{mg} / \mathrm{kg}$ live weight. The remaining six animals (three $\mathrm{Zn}$-deficient and three controls) were not dosed with colchicine. Both colchicine-dosed and undosed animals were killed $6 \mathrm{~h}$ after administration of the drug.

\section{Materials and methods}

Immediately at death, the first $20 \mathrm{~mm}$ of the duodenum was excised and the end distal to the pyloric sphincter was diced to $1 \mathrm{~mm}^{3}$ blocks under cold glutaraldehyde solution ( $50 \mathrm{~g} / 10.06 \mathrm{M}$-sodium cacodylate buffer, $\mathrm{pH} 7.2$ ) or in Palade's osmium tetroxide fixative, for electron microscopy. The remaining tissue was immersed in formaldehyde solution ( $40 \mathrm{~g} / 1 \mathrm{O}^{\circ} \mathrm{I} \mathrm{M}$-sodium chloride) for subsequent paraffin-wax impregnation. Glutaraldehyde fixation was continued for $4 \mathrm{~h}$ at $4^{\circ}$ before post-fixation in Palade's solution. Tissues so treated were subsequently stained en bloc with uranyl acetate before embedding in Araldite (BDH Ltd, Poole, Dorset). Survey sections I $\mu \mathrm{m}$ thick were cut vertically through the villi and stained with toluidine blue for light microscopy. Silver-gold sections from selected areas were stained with lead citrate before examination in an electron microscope AEI 80IA (AEI Scientific Apparatus Ltd, Barton Dock Road, Urmston, Manchester). Three survey ( $1 \mu \mathrm{m}$ ) sections of two samples from each animal were assessed for incidence of necrotic bodies by using an 
Table $\mathrm{x}$. Expt $\mathrm{x}$. Incidence of lesions* in $\mathrm{x} \mu \mathrm{m}$ sections from the duodenal crypts of groups of zinc-deficient and pair-fed control rats treated with different amounts of colchicine $\dagger$

\begin{tabular}{lcc} 
I & \multicolumn{2}{c}{$\begin{array}{c}\text { Colchicine } \\
\text { (mg/kg live weight) }\end{array}$} \\
Zn-deficient & 5.0 & 7.6 \\
Controls & 3.9 & 5.4
\end{tabular}

* Arithmetic mean of recognizable bodies per randomly selected square of side $50 \mu \mathrm{m}$.

+ For details of experimental treatments, see p. 136 .

eye-piece graticule to superimpose a net of $5^{\circ} \mu \mathrm{m}$ squares over the crypts of the mucosa. From each section, nine squares were selected at random and the number of enclosed bodies recognizable at a magnification of $\times 500$ was recorded. The total count, for each animal, obtained by this method was analysed to determine the treatment effects and interaction. The effects were expected to be multiplicative rather than additive and so the logarithms of these totals were analysed statistically.

\section{RESULTS}

Colchicine administration resulted in the formation of rounded cytoplasmic inclusions within the rapidly proliferating crypt cells of the duodenal mucosa but none were evident in the mature cells of the villi. The bodies contained an eosinophilic background material in which Feulgen-positive basophilic inclusions were scattered.

Individual bodies ranged from 0.5 to $8.0 \mu \mathrm{m}$ in diameter and were usually enclosed by a double membrane. Their contents showed a variable extent of morphological preservation but mainly consisted of mitochondrial figures (Plate (I)) together with traces of endoplasmic reticulum and, more rarely, nuclear material. Many of the inclusions were found in close proximity to a Golgi apparatus.

Lesions were found in the duodenal mucosa of all colchicine-treated animals but were absent from control $\mathrm{Zn}$-deficient and $\mathrm{Zn}$-supplemented animals. The incidence of lesions was calculated as the arithmetic mean of recognizable bodies per selected square of side $50 \mu \mathrm{m}$ (Table I). The increased incidence of necrosis, at I or $2 \mathrm{mg} / \mathrm{kg}$ live weight levels of colchicine administration, in $\mathrm{Zn}$-deficient animals was strikingly evident in survey sections (Plate $(2$ and 3$)$ ) and confirmed by this quantitative assessment.

These experiments were designed so that the $\mathrm{Zn}$ effect and the $\mathrm{Zn} \times$ colchicine interaction were based on within-pair comparisons and the colchicine effect was based on between-pair comparisons. It was noted that the rats on the lowest colchicine level $(0.2 \mathrm{mg} / \mathrm{kg}$ live weight in Expt I) had insufficient lesions for reliable assessment and so the statistical analysis was restricted to the results from the rats on 1 or $2 \mathrm{mg} / \mathrm{kg}$ live weight of colchicine (eight rats in Expt $I$ and twelve in Expt 2). The variable examined in both experiments was the logarithm of the total count of lesions. One analysis was carried out on the sums for each pair, and one on the differences. For each analysis the residual mean square was combinable for the two experiments so the 
Table 2. Expts I and 2. Log no. of lesions in I $\mu$ m sections from duodenal crypts of groups of zinc-deficient and pair-fed control rats treated with different amounts of colchicine*

\begin{tabular}{|c|c|c|c|}
\hline \multicolumn{4}{|c|}{$\begin{array}{l}\text { (Mean value for each treatment averaged over both experiment } \\
\text { the derived number of lesions is given in parentheses) } \\
\text { Colchicine ( } \mathrm{mg} / \mathrm{kg} \text { live weight) }\end{array}$} \\
\hline & $\mathbf{I}$ & 2 & $\begin{array}{l}\text { Mean for } \\
\text { each group } \\
\text { of rats }\end{array}$ \\
\hline $\mathrm{Zn}$-deficient & $\begin{array}{l}2 \cdot 434 \\
(272)\end{array}$ & $\begin{array}{l}2 \cdot 617 \\
(414)\end{array}$ & $\begin{array}{l}2 \cdot 526 \\
(336)\end{array}$ \\
\hline Controls & $\begin{array}{l}2 \cdot 326 \\
(212)\end{array}$ & $\begin{array}{r}2 \cdot 465 \\
(292)\end{array}$ & $\begin{array}{l}2 \cdot 396 \\
(249)\end{array}$ \\
\hline \multirow[t]{2}{*}{$\begin{array}{l}\text { Mean for each } \\
\text { colchicine treatment }\end{array}$} & $\begin{array}{l}2 \cdot 380 \\
(240)\end{array}$ & $\begin{array}{l}2 \cdot 541 \\
(348)\end{array}$ & - \\
\hline & & $\begin{array}{l}\text { Individual } \\
\text { treatment } \\
\text { means }\end{array}$ & $\begin{array}{l}\text { Overall } \\
\text { colchicine } \\
\text { or } \mathrm{Zn} \text { means }\end{array}$ \\
\hline \multicolumn{2}{|c|}{$\begin{array}{l}S E \text { of difference between mean values } \\
\text { for colchicine treatments ( } 6 \mathrm{df})\end{array}$} & $0.06 \mathrm{I}$ & 0.043 \\
\hline \multicolumn{2}{|c|}{$\begin{array}{l}\text { SE of difference between mean values } \\
\text { for zinc treatments }(6 \mathrm{df})\end{array}$} & $0.04 \mathrm{I}$ & 0.029 \\
\hline
\end{tabular}

pooled value was used (with $6 \mathrm{df}$ ) to test whether there was any evidence that the treatment effects differed in the two experiments.

The colchicine effect was significant $(P<0.01)$, in that doubling the dose of colchicine increased the number of lesions by $46 \pm 10 \%$ (SE). The $\mathrm{Zn}$ effect was also significant $(P<0.01)$. The presence of $\mathrm{Zn}$ led to a $26 \pm 6 \%$ (SE) reduction in the number of lesions. There was no evidence that these effects differed between the two experiments or of any interaction between $\mathrm{Zn}$ and colchicine.

The means of the log values with the retransformed counts are given in Table 2.

\section{DISCUSSION}

The results of these experiments confirm the finding of Fell et al. (1973) that, in the rat, the $\mathrm{Zn}$-deficiency state is associated with an increased sensitivity to colchicine toxicity, in certain tissues.

Colchicine is best known as an inhibitor of mitosis in dividing cells (Eigsti \& Dustin, 1955), an effect which may now be attributed to the binding of colchicine with the dimer subunit of the microtubular protein, tubulin (Taylor, 1965 ; Borisy \& Taylor, $1967 a, b)$ thus disturbing the dynamic equilibrium between free and aggregated microtubular units. Differences in the sensitivity of various organs to colchicine poisoning may be related to the frequency of a polymerization-depolymerization cycle (Patzelt, Singh, Le Marchand, Orci \& Jeanrenaud, r 975); an increased sensitivity to colchicine may, therefore, be associated with a reduced stability of intact microtubules and a concomitant increase in the amount of colchicine-binding material. 
The high incidence of cytoplasmic inclusions observed in these experiments suggests that many more cells were affected than those in division. The influence of dosage on the incidence of these lesions has been studied by Dinsdale (1975).

The bodies observed are probably involved in the deletion of growing crypt cells and may result from the sequestration of damaged areas of the cytoplasm or from endocytosis of debris resulting from the death of a neighbouring cell (Dinsdale, 1975). Such a process was described in detail by Kerr, Wyllie \& Currie (I972) and termed 'apoptosis'. 'Though occurring in normal tissues, the process is much more marked during atrophy or in response to noxious agents.

Whether a specific effect of colchicine on microtubular protein may be related to the effects we have observed cannot be stated with any certainty. Colchicine is reported to affect in vivo the activity of a wide variety of enzymes (Eigsti \& Dustin, I955; Myren, Luketic, Ceballos, Sachs \& Hirschowitz, I966). Significantly, however, Myren et al. (1966) were unable to demonstrate any inhibition in vitro of any of five dehydrogenases studied in mouse gut. It was suggested by these authors that a reduction in the in vivo activity of some of the enzymes, assessed by histological staining techniques, might be explained by a loss of enzyme into surrounding tissue or circulation. Increased xanthine oxidase activity $(E C$ I.2.3.2) in rat serum after colchicine administration appears to be related to the loss of this enzyme from liver tissue (Affonso, Mitidieri \& Villela, 1961, 1962). Colchicine did not affect xanthine oxidase activity in a liver homogenate, but was a powerful inhibitor of the purified enzyme. An increase in rat liver alkaline phosphatase (EC 3.I.3.I) activity, after colchicine administration, was significantly higher $18 \mathrm{~h}$ after dosing (Ebner \& Streckner, 1950). Substantial reductions in ATP levels were found in both normal and regenerating rat liver $8 \mathrm{~h}$ after colchicine administration (Wang, Greenbaum \& Harkness, 1963) an effect which was still apparent $16 \mathrm{~h}$ later, by which time the antimitotic effects of the drug are essentially over (Clearkin, 1937). The lack of any timedependent relationship between the effects of colchicine on enzyme function or substrate levels and mitotic arrest suggests that these properties of the drug are quite separable. It would, therefore, appear that colchicine-induced enzyme changes may be related to varying amounts of cell damage which may, initially, be attributable to the effects of the drug on the cell membrane; the distinction between cause and effect remains obscure.

The earliest directly observable clinical effect of $Z n$ deficiency in the rat is a reduction in growth rate ('Todd, Elvejhem \& Hart, 1934). There is considerable evidence that $\mathrm{Zn}$ is required for DNA synthesis, or, more correctly, for processes involved in the incorporation of labelled precursors into the DNA of various tissues (Lieberman, Abrams, Hunt \& Ove, 1963; Fujioka \& Lieberman, 1964; Williams, Mills, Quarterman \& Dalgarno, I965; Weser, Seeber \& Warnecke, 1968; Swenerton, Shrader \& Hurley, 1969; Williams \& Chesters, 1970). Paradoxically, however, an increase in the rate of cell division in the $\mathrm{Zn}$-deficiency state was observed by Fell et al. (1973), notably in the oesophagus and pancreas, and a stimulation of $\left[{ }^{3} \mathrm{H}\right]$ thymidine incorporation into the DNA of the thymus of $\mathrm{Zn}$-deficient rats was noted by Stephan \& Hsu (I973).

Mazia (1961) has pointed out that a high mitotic index may result from an increase 
Table 3. Duration of mitosis and intermitotic period (min) in selected tissues of the rat

\begin{tabular}{llcc}
\multicolumn{1}{c}{ Tissue } & Source & $\begin{array}{c}\text { Intermitotic } \\
\text { time (min) }\end{array}$ & $\begin{array}{c}\text { Mitotic } \\
\text { time (min) }\end{array}$ \\
Corneal epithelium & Mazia (196I) & 14000 & 70 \\
Jejunal epithelium & Mazia (196I) & 2000 & 28 \\
Oesphagus (control) & Present study & $2 \mathrm{r} 000$ & ro8 \\
Oesphagus (zinc-deficient) & Present study & I 300 & 20
\end{tabular}

in the number of cells entering division, a protraction of the mitotic time or the existence of a wave of division.

An increase in the rate of cell division in certain tissues would result in a larger proportion of cells being susceptible to mitotic poisoning by colchicine, more cells would therefore be arrested at metaphase and subsequently destroyed. A close relationship between mitosis and apoptosis has been indicated in earlier studies (Kerr et al. 1972; Wyllie, Kerr \& Currie, 1973) which suggests that an increased mitotic rate may be, in part, a response to increased cell deletion.

From the data of Fell et al. (1973) it can be calculated (Table 3) that the rate of cell division in the $\mathrm{Zn}$-deficient rat oesophagus reverts to that characteristic of the lower gut, a finding consonant with the hypothesis of Chesters (1974) that de-differentiation of the genetic potential of the cell may occur in $\mathrm{Zn}$ deficiency, a process which may be more susceptible to $\mathrm{Zn}$ deficiency than is DNA synthesis. Searle, Lawson, Abbot, Harmon \& Kerr (1975), suggest the possible involvement of 'apoptosis' in the deletion of abnormalities of DNA (gene?) expression.

If changes in mitotic times are considered a further paradox is demonstrable. Swenerton et al. (1969) reported that, while $\left[{ }^{3} \mathrm{H}\right]$ thymidine incorporation in foetuses of $\mathrm{Zn}$-deficient female rats was considerably reduced as compared with controls, a greater number of unlabelled mitotic figures were to be found in the neuroepithelium. This suggests that these figures resulted from a greater number of cells which had entered division before the administration of the isotope or in which mitotic cleavage had been delayed, in analogy to the effects of colchicine. In the severely $\mathrm{Zn}$-deficient rat testis, Elmes (1974) observed abnormal mitotic figures, similar to those which may be induced by colchicine poisoning (Eigsti \& Dustin, 1955), and in the $\mathrm{Zn}$-deficient sheep colchicine administration resulted in gross disturbances to terminal nerveendings in tongue epithelium, whereas a normal animal was not affected (Mann, Fell \& Dalgarno, 1974).

Edstrom \& Mattson (1975) have reported that $\mathrm{Zn}$ has a role in the microtubulardependent axonal transport of protein in frog sciatic nerve.

It is suggested therefore in accord with the views of Nickolson \& Veldstra (1972) that $\mathrm{Zn}$ has a role in the functioning of microtubular structures in the cell, and that, in the $\mathrm{Zn}$-deficiency state certain manifestations may be a reflection of changes in the dynamic equilibrium of these important cell components, thus resulting in increased susceptibility to the effects of colchicine toxicity. 
We would like to thank Mr A. W. Boyne for statistical analysis of the results, Miss Sheila Fraser for technical assistance and also Mrs Norma McKenzie for her care of the animals.

\section{REFERENCES}

Affonso, O., Mitidieri, E. \& Villela, G. G. (I961). Nature, Lond. r92, 666. Affonso, O., Mitidieri, E. \& Villela, G. G. (1962). Nature, Lond. 193, 640. Alov, I. A. (1963). Fedn. Proc. Fedn. Am. Socs. exp. Biol. Med. 22, T357.

Back, A., Walaszek, E. J. \& Uyeki, E. (195I). Proc. Soc. exp. Biol. Med. 77, 667.

Borisy, G. G. \& Taylor, E. W. (1967a). \%. Cell Biol. 34, 525.

Borisy, G. G. \& Taylor, E. W. (1967b). F. Cell Biol. 34, 535.

Chesters, J. K. (1974). In Trace Element Metabolism in Animals. Vol. 2, pp. 39-50 [W. G. Hoekstra, J. W. Suttie, H. E. Ganther and W. Mertz, editors]. Baltimore: University Park Press.

Clearkin, P. A. (I937). F. Path. Bact. 44, 469.

Diamond, I. \& Hurley, L. S. (1970). F. Nutr. 100, 325.

Dinsdale, D. (1975). Path. Eur. 10, 95.

Ebner, H. \& Strecker, H. (1950). Experientia 6, 388.

Edstrom, A. \& Mattson, H. (1975). Brain Res. 86, 162.

Eigsti, O.J. \& Dustin, P. (1955). In Agriculture Medicine, Biology and Chemistry, p. I75. Ames, Iowa: Iowa State College Press.

Elmes, M. E. (1974). Studies on the role of the Paneth cell in zinc metabolism in the rat. PhD Thesis, Queen's University of Belfast, Northern Ireland.

Fell, B. F., Leigh, L. C. \& Williams, R. B. (1973). Res. vet. Sci. x4, 317.

Fujii, T. (1954). Nature, Lond. I74, 1108.

Fujii, T. (1955). F. Fac. Sci. Tokyo Univ. 7, 313.

Fujioka, M. \& Lieberman, I. (1964). F. biol. Chem. 239, i I64.

Hurley, L. S. \& Swenerton, H. (1966). Proc. Soc. exp. Biol. Med. 123, 692.

Kerr, J. F. R., Wyllie, A. H. \& Currie, A. R. (1972). Br. F. Cancer 26, 239.

Lieberman, I., Abrams, R., Hunt, N. \& Ove, P. (1963). F. biol. Chem. 238, 3955 .

Mann, S. O., Fell, B. F. \& Dalgarno, A. C. (1974). Res. vet. Sci. 17, 91.

Mazia, D. (I96I). In The Cell, vol. 3, p. 77 [J. Brachet and A. E. Mirsky, editors]. New York and London: Academic Press.

Mills, C. F., Quarterman, J., Williams, R. B., Dalgarno, A. C. \& Panic, B. (1967). Biochem. F. 102, 712. Morisawa, M. \& Mohri, H. (1972). Exp. cell Res. 70, 3 Ir.

Myren, J., Luketic, G. C., Ceballos, R., Sachs, G. \& Hirschowitz, B. I. (I966). Am. F. dig. Dis. II, 394. Nickolson, V. J. \& Veldstra, H. (1972). FEBS Letters 23, 303.

Patzelt, C., Singh, A., Le Marchand, Y., Orci, L. \& Jeanrenaud, B. (1975). F. Cell Biol. 66, 609.

Prasad, A. S., Oberleas, D., Wolf, P. \& Horwitz, J. P. (1967). F. clin. Invest. 46, 549.

Reinhold, J. G., Kfoury, G. A. \& Thomas, T. A. (1967). F. Nutr. 92, 173.

Searle, J., Lawson, T. A., Abbot, P. J., Harmon, B. \& Kerr, J. F. R. (1975). Y. Path. 116, 129.

Stephan, J. K. \& Hsu, J. M. (1973). F. Nutr. 103, 548.

Swenerton, H., Shrader, R. \& Hurley, L. S. (1969). Science, N.Y. 166, Ior4.

Taylor, E. W. (1965). F. Cell Biol. 25, 145.

Todd, W. R., Elvejhem, C. A. \& Hart, E. B. (1934). Am. F. Physiol. ro7, 146.

Wang, D. Y., Greenbaum, A. L. \& Harkness, R. D. (1963). Biochem. F. 86, 62.

Weisenberg, R. C., Borisy, G. G. \& Taylor, E. W. (1968). Biochemistry 7, 4466.

Weser, V., Seeber, S. \& Warnecke, P. (1968). Biochim. biophys Acta 179, 422.

Williams, R. B. (1972). Br. F. Nutr. $27,121$.

Williams, R. B. \& Chesters, J. K. (1970). Br. F. Nutr. 24, 1053.

Williams, R. B. \& Mills, C. F. (1970). Br. F. Nutr, 24, 989.

Williams, R. B., Mills, C. F., Quaterman, J. \& Dalgarno, A. C. (1965). Biochem. Y. 95, 29 P.

Wyllie, A. R., Kerr, J. F. R. \& Currie, A. R. (1973). F. Path. xIx, 255. 


\section{EXPLANATION OF PLATE}

(1) Electron micrograph of two intracellular necrotic bodies from the duodenum of a zinc-deficient rat $6 \mathrm{~h}$ after administration of $\mathrm{rmg} / \mathrm{kg}$ colchicine. $\times 19000$. (2) Survey section through the duodenum of a zinc-supplemented rat, $6 \mathrm{~h}$ after administration of $\mathrm{I} \mathrm{mg} / \mathrm{kg}$ colchicine, showing the presence of necrotic bodies. $\times 350$. (3) Survey section through the duodenum of a zinc-deficient rat, $6 \mathrm{~h}$ after administration of $\mathrm{I} \mathrm{mg} / \mathrm{kg}$ colchicine, showing an increased incidence of necrotic bodies. $\times 350$. 


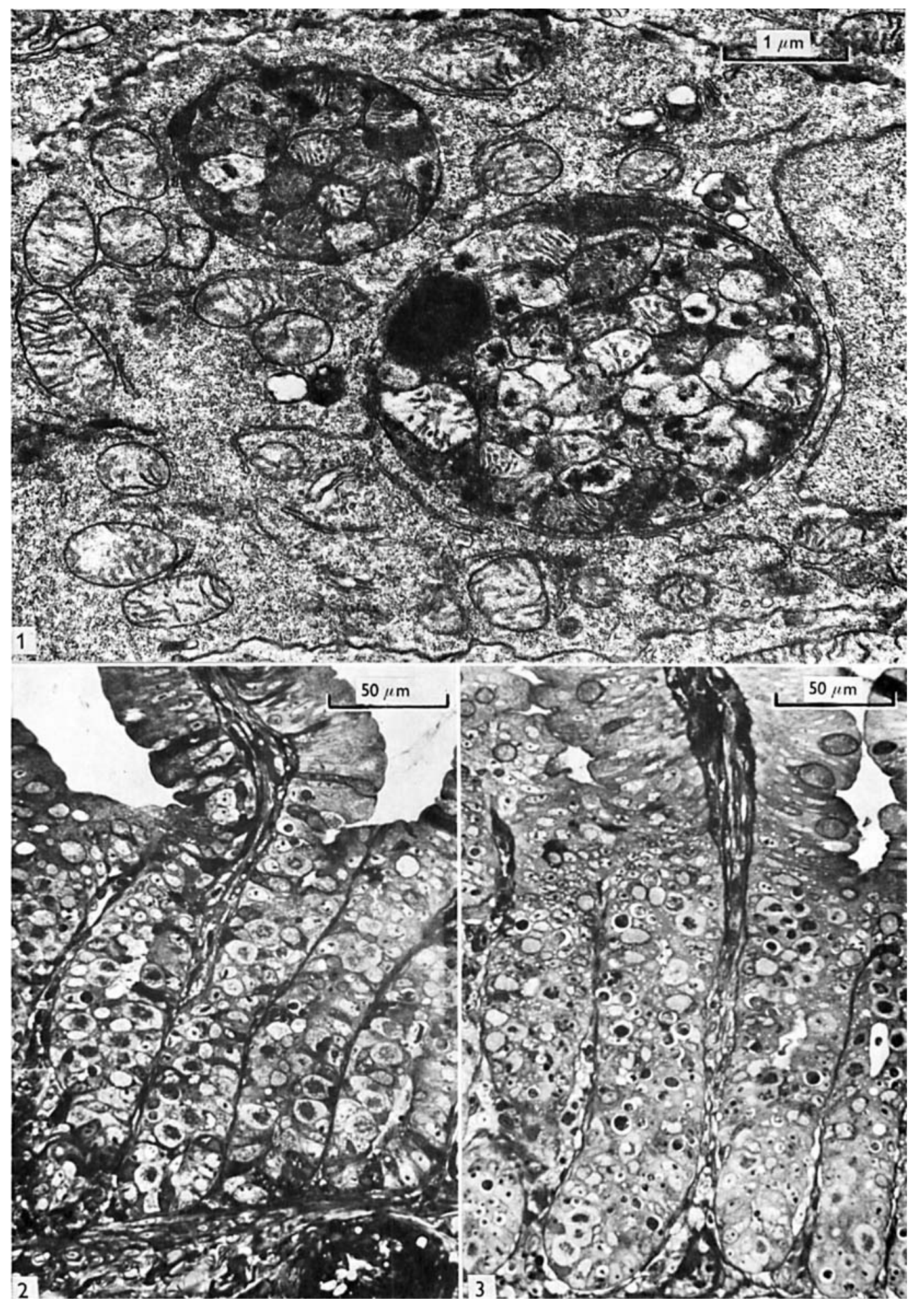

